\title{
Proceeding
}

Supplementary Issue: Spring Conferences of Sports Science. Costa Blanca Sports Science Events, 14-15 June 2019. Alicante, Spain.

\section{Experimental evaluation of the school well-being improvement for primary school students through a water polo sports laboratory}

\author{
DAVIDE DI PALMA, SALVATORE IOVINO, ANTONIO ASCIONE \\ Department of Sport and Well-being Sciences, Parthenope University, Naples, Italy
}

\begin{abstract}
The concept of well-being can be now extended to all social environments that provide a relational system between the various individuals, and among these environments, one of the most important is certainly school. The purpose of this contribution is to show the concept of school well-being and then analyze if an experimental proposal of a sports laboratory could be an effective pedagogical strategy, capable of improving the level of well-being for students. In this regard, at primary school level, a laboratory activity on water polo was provided, and through the QBS-B questionnaire, the change in the level of school well-being perceived by the students, from the "pre" Laboratory period to the "post" one, was assessed. Keywords: School wellbeing; Sports laboratory; Experimental pedagogy; Water polo; Primary school.
\end{abstract}

\section{Cite this article as:}

Di Palma, D., lovino, S., \& Ascione, A. (2019). Experimental evaluation of the school well-being improvement for primary school students through a water polo sports laboratory. Journal of Human Sport and Exercise, 14(4proc), S885-S895. doi:https://doi.org/10.14198/jhse.2019.14.Proc4.51

Corresponding author. Department of Sport and Well-being Sciences, Parthenope University, Naples, Italy.

E-mail: antonio.ascione@uniparthenope.it

Supplementary Issue: Spring Conferences of Sports Science. Costa Blanca Sports Science Events, 14-15 June 2019. Alicante, Spain.

JOURNAL OF HUMAN SPORT \& EXERCISE ISSN 1988-5202

(c) Faculty of Education. University of Alicante

doi:10.14198/jhse.2019.14.Proc4.51 


\section{INTRODUCTION}

School, especially that of primary education, is one of the most important and fundamental environments for the training of the individual, both from a didactic point of view, but above all from a pedagogical one, which also considers all the implications of a training development such as to affect the life of each individual. In this regard, it seems considerably interesting that the conditions of this socio-relationship environment are the most suitable so that each student (in the case of primary schools, each child) is potentially able to proceed effectively in his growth path. For this purpose, the concept of school well-being is supported, which analyses the main key factors that influence the student and that determine his / her learning and sociorelationship development and personal growth abilities (and willingness).

This work aims to evaluate the ability of a sports laboratory, centred on a team sport such as water polo, to influence school well-being and, in this case, to represent an important experimental pedagogical proposal for the whole school system.

\section{School well-being}

Well-being is a complex construct, the subject of many theories and examined in the psychological, philosophical, medical, political and many other fields (Allison, Locker and Feine, 1997; Crocetti, 2014; Diener and Larsen, 1993; Mariani, 2001; Maslow, 1970; Petrillo, 2008; Ryan and Deci, 2001; Varni, Seid and Rode, 1999).

While, in the past, the concept of well-being (also called "life quality") was identified in the absence of malaise, more recently the focus has shifted on the positive aspects of the individual's functioning with respect to the physical, mental and social domains, taking into consideration physical and psychological health, the quality of family and non-family relationships, adaptive skills, self-esteem, a sense of self-efficacy and emotional experience in different life situations, such as family, work and especially school life (Crocetti, 2014, Petrillo, 2008; Steca, Ryff, D'Alessandro and Delle Fratte, 2002). Furthermore, this construct can include two different perspectives: the subjective one of an individual who understands the perception people have of their own social relationships, activities and goals, and the level of satisfaction for their life, both globally and in relation to single domains, and the objective one concerning the living conditions, the quality of the environment or the socio-cultural and economic conditions in which people live.

Taking into consideration the individuals in the development age, the school environment represents the place in which the child or young person experiences many relational, emotional and cognitive levels; experiences based on which one develops ideas about oneself (self-esteem, self-efficacy), ideas about others and the relationship he/she can have with them. School is therefore one of the most important environments for children, and from this, the need to evaluate the aspects of well-being linked to this context emerges (Crocetti, 2014, Mariani, 2001; Petrillo, 2008). To carry out an assessment of the child's well-being at school, it is important to consider what are the elements influencing his/her life at school, taking into consideration the psycho-pedagogical literature and the educational practice carried out by operators in the school context, in particular teachers, school psychologists and pedagogists.

From the studies on the link between motivation and success, we know that the child who has experienced school success will develop positive beliefs about his/her own skills (sense of self-efficacy), and will be more motivated to repeat the behaviours that led him to a good school achievement, favouring the repetition of positive experiences. This creates a vicious circle that, together with school success, guarantees the child well-being experiences linked to a good sense of self-efficacy (judgments related to his/her own skills) and 
self-esteem (judgments related to his/her own value). Let us consider an opposite situation: an experience of school failure is often accompanied by a lack of motivation, which implies the distancing and detachment from a situation that children consider to be at risk of failure. The idea that children and young people have of their school success, and how much this is recognized by parents and teachers, is another of the main elements to which attention must be paid for an effective assessment. Perceived self-efficacy is closely related to it, particularly with respect to one's own cognitive and learning skills. Sense of self-efficacy, conviction of self-efficacy or perceived self-efficacy, correspond to the convictions about one's own abilities to organize and carry out the sequences of actions necessary to generate certain results (Bandura et al, 2007; Caprara, 2001).

The starting hypothesis of this work is that a sports laboratory centred on a team discipline such as water polo can positively stimulate these socio-pedagogical dynamics, and contribute to an increase in the level of school well-being perceived by the students; therefore, it can favour a training development both in the school context, but also in all the many relational environments that influence the individual's life.

\section{Water polo for school-age children}

Water polo is also a sport suitable for children aged $7 / 8$ years too, as it contributes to both physical, motor and socio-educational development (Di Palma, Ascione, Masala, 2018).

Specifically, water polo for children of this age is called water goal and sees two teams facing each other, each represented in the field by seven players, just like in the higher categories. When swimming, athletes must throw a ball with their hands, as many times as possible, into the opponent's goal. Below are summarized all the main determinants that characterize this sport, and which are common to any age and level it gets practiced (Di Palma, Ascione, Belfiore, 2018; Di Palma, Ascione, Masala, 2018; Gatta, 2009; Napolitano et al, 2013):

- It is a team sport;

- $\quad$ It is a water sport, in which it is essential to know how to swim well;

- It is a situational sport, in which every action of the game is unexpected: depending on how the game develops, the action can take different directions;

- It is an aerobic sport, where efforts are distributed over time and provide for sufficient recovery times;

- It is a sport of "contact", involving actions where a player must defend and one must attack, but with very specific rules that highly penalize those who should commit "serious" fouls.

"Water goal" category (7-8 years)

What differentiates the water polo practiced by school-age children, aged between 7 and 8 years old, is certainly the development of the fundamentals and adaptations of the regulation that tend to favour the educational, social and playful development of this sport. Taking into account the age and the non-evolved technical level of the skills of young players, in fact, the following rules are applied:

- $\quad$ The aim of the game is to let the ball enter the opponent's goal, thus scoring a point;

- $\quad$ For each match, the teams are composed of a minimum of 7 to a maximum of 13 players, possibly of both sexes, of which 6 must be simultaneously in the water plus the goalkeeper;

- $\quad$ The dimensions of the field are: width 8/15 meters, length 20/25 meters, minimum depth of 1 meter; 
- $\quad$ The ball used is the number $3(15-18 \mathrm{~cm}$ in diameter / 7 inches $)$, with a weight of $230-260$ grams;

- The dimensions of the doors are: a) width $\mathrm{m} .1 .50$ - height $\mathrm{m} .0 .80 \mathrm{~b}$ ) width $\mathrm{m} .2 .15$ - height m. 0.75 ;

- $\quad$ The meetings last 2 halves of 10 minutes each, with a 3-minute break;

- $\quad$ Touching the ball with two hands is not considered a foul, provided that the throw and the pass must be made with one hand only;

- $\quad$ Leaning on the bottom and sinking the ball is not considered a foul;

- $\quad$ Off-game (in water polo jargon commonly called "2-meter foul") is abolished;

- In case of temporary expulsion, the sanctioned player will have to reach his corner and will be replaced by another player;

- $\quad$ After a foul, the player can never shoot directly on goal;

- Definite expulsion is foreseen after 4 serious faults, sanctioned by temporary expulsion;

- $\quad$ The goalkeeper can be substituted in the interval between the 2 halves of the game and after the goal (been conceded or realized), but in this case the time will not be interrupted. The player who substitutes the goalkeeper must wear a red cap.

Under 11 category (9-11 years)

The Under 11 category is the link between recreational activities and competitive water polo. The larger field size and the adoption of 'intermediate' measurement doors allow for a more structured water polo game. What skills does the child develop?

Children of this age group are taught fundamental, basic techniques in water polo, including the use of the ball, collaboration with teammates and different swimming techniques than the usual ones:

- $\quad$ Alternate breaststroke,

- $\quad$ Freestyle with the head out of the water,

- Backstroke with the head out of the water.

These techniques are then refined with the aim of being able to support a more fluid and facilitating game in terms of physical effort.

This develops (Di Palma, Ascione, Belfiore, 2018; Di Palma, Ascione, Masala, 2018; Gatta, 2009; Guetano, Lipoma, Tafuri, 2015; Napolitano et al, 2013):

- Motor skills: coordination, lung capacity development and cardiovascular system functions, increased resistance, harmonious body development;

- $\quad$ Cognitive skills: problem-solving and decision-making;

- $\quad$ Socio-relational skills: the fact of being part of a team allows the child to develop good interpersonal skills, learn to respect the rules and their own mates, by stimulating team spirit, friendship and collaboration;

- Emotional skills: respect for the rules and for one's own mates, stimulating team spirit, management of victory and defeat, respect for rules and respect for the opponent;

- Technical skills: the use of the ball, the collaboration with one's own mates and the different swimming techniques than the usual ones: alternate breaststroke, freestyle with the head out of the water, and backstroke with the head out of the water. 
It is also of fundamental importance to then approach the experimental phase, and to describe, albeit briefly, the structure of a set of standard training sessions that can be proposed to young athletes of the age group taken into consideration. The ideal training involves a warm-up phase outside the water, which anticipates the entrance into the pool. The depth of the water is given by the height of the lower child's chest. Children are explained the first specific movements of water polo: from the use of the ball to the first physical contacts with other teammates. Continuing in the lessons, the ball is integrated as a natural element, the collaboration in pair exercises becomes a challenge, and the first instructions for team tactics begin to be introduced. Athletes then learn to feel the water and the ball at the same time, and exercises will be introduced to improve ball catch. In water goal children practice mainly games in the water and with the ball, in order to make them become familiar with these elements. Basically, it needs that children already have good swimming skills, in order to have to train them on the characteristic elements of water polo.

What described above is the basis for the assessment of the implementation of a "sports laboratory" activity in the school context, which includes the practice of water polo as the main component, aimed at analysing if and with what intensity it is able to improve the "school well-being" of students.

\section{Experimental didactic-pedagogical proposal}

The experimental planning in the didactic-pedagogical field has been implemented in a primary school class, in order to evaluate the ability to increase the level of school well-being perceived by the students through the sports practice carried out in a laboratory activity focused on water polo.

\section{METHOD}

It is essential to start by saying that the experimentation was based on the collaboration and skills of the physical education and sports manager of the "sample" class (the object of this project) and of a federal water polo technician; all this is a swimming facility that holds an agreement with the school.

The sample consisted of students of a third-year primary school class: 14 Males $(M)$ - 6 Females $(F)$ Average age 8.1 years.

A subdivision was made into 2 periods: T0 (activity start) - T1 (end of the activity).

Duration: 4 Months - 2 Weekly Meetings of 1 hour each - For a total of 32 Meetings (32 hours).

Maximum number of hours of absence for the student to be considered valid element in the experimentation: 4 hours.

The first month of activity was entirely dedicated to the water setting, in order to allow each student carrying out the proposed activity.

The activity was oriented both to the learning of the fundamental rules and to the playful aspect of water polo, with an orientation towards the exercises that included the use of the ball and the doors. In all the meetings, starting from the second month, the last 15 minutes were dedicated to friendly practice matches with mixed teams and without taking note of the score, in order to favour constructive fun over competitive spirit and in a socio-pedagogical key. 


\section{Assessment tool}

The tool used for the Assessment was the Questionnaire for the Assessment of School Well-being for Children (QBS-B) (Mazzocchi, Tobia, 2015).

The questionnaire consisted of 27 items and allowed calculating a total score of School Well-being, resulting from the partial scores related to the following subscales:

1. Satisfaction and recognition: 4 items that investigate the students' satisfaction with their academic achievements, and the perception that their commitment and skills are recognized by parents and teachers;

2. Relationship with teachers: 5 items that examine the level of trust in teachers, and the perception that the students have of their emotional availability, support and recognition;

3. Relationship with classmates: 5 items that evaluate the experience of acceptance by the class group, the level of trust towards the classmates and the presence of significant friendships;

4. Emotional attitude at school: 4 items that evaluate the emotional reactions of children/young subjects in dealing with school requests, going deep into the experiences of anxiety, shame and sense of guilt;

5. Sense of self-efficacy: 6 items that assess the students' self-efficacy perception, taking into account their point of view on some qualities related to the cognitive and learning environment.

There are also 3 items that are not employed for the purpose of calculating the School Well-being score, but they can be of help for a qualitative assessment of the causal attribution mechanisms implemented by the child. Each QBS item requires a response on a 3-point Likert scale with the following labels: not true, fairly true, very true. Children must choose directly between the three labels, and the score then assigned by the examiner for each item is respectively 0,1 or 2 points, with some exceptions for negative items, which will have inverse attribution. The 5 subscales of QBS-B and QBS-R consist of a different number of items; in order to allow for the comparison between the different subscales, it is therefore necessary to calculate the average score obtained at each subscale. Almost all the items are positive, so the answer "not true" corresponds to a score of 0 , the answer "fairly true" to a score of 1 and the answer "very true" to a score of 2. Exceptions are items 9,12 and 22 of the subscale Emotional attitude at school, for which it needs to reverse the score, so that the answer "not true" corresponds to a score of 2, the answer "fairly true" to a score of 1 and the answer "very true" to a score of 0 .

Below are the tables for calculating subscale scores. From the sum of the average scores of the 5 subscales, the total score of the child's school Well-being is obtained. Higher scores correspond to greater well-being perceived by students.

Table 1. Subscale Satisfaction and recognition

\begin{tabular}{|c|l|c|c|c|}
\hline N. & \multicolumn{1}{|c|}{ Item } & Not true & Fairly true & Very true \\
\hline 1 & I am satisfied with the school results I get & 0 & 1 & 2 \\
\hline 19 & My parents are happy with the way I work at school & 0 & 1 & 2 \\
\hline 23 & My parents believe that I do my best in the study & 0 & 1 & 2 \\
\hline 25 & My teachers are happy with the way I work at school & 0 & 1 & 2 \\
\hline \multicolumn{2}{|c|}{ Scale total score } \\
\hline
\end{tabular}


Table 2. Subscale Relationship with teachers

\begin{tabular}{|l|l|c|c|c|}
\hline $\mathbf{N}$. & \multicolumn{1}{|c|}{ Item } & Not true & Fairly true & Very true \\
\hline 11 & I feel at ease with my teachers & 0 & 1 & 2 \\
\hline 15 & my teachers know how to convince me to do my best & 0 & 1 & 2 \\
\hline 18 & I trust my teachers & 0 & 1 & 2 \\
\hline 20 & My teachers support me if I don't understand something & 0 & 1 & 2 \\
\hline 24 & I can talk to my teachers about my concerns and difficulties & 0 & 1 & 2 \\
\hline \multicolumn{2}{|r|}{ Scale average (total score / 5) } \\
\hline
\end{tabular}

Table 3. Subscale Relationship with classmates

\begin{tabular}{|c|l|c|c|c|}
\hline $\mathbf{N}$. & \multicolumn{1}{|c|}{ Item } & Not true & Fairly true & Very true \\
\hline 4 & My mates like working with me & 0 & 1 & 2 \\
\hline 10 & I have got many friends in my class & 0 & 1 & 2 \\
\hline 17 & I feel accepted in my class & 0 & 1 & 2 \\
\hline 21 & I have fun with my mates & 0 & 1 & 2 \\
\hline 27 & I can trust my mates & 0 & 1 & 2 \\
\hline
\end{tabular}

Table 4. Subscale Emotional attitude at school

\begin{tabular}{|c|l|c|c|c|}
\hline $\mathbf{N}$. & \multicolumn{1}{|c|}{ Item } & Not true & Fairly true & Very true \\
\hline 6 & I feel quiet before a written or oral test & 0 & 1 & 2 \\
\hline 9 & $\begin{array}{l}\text { I feel anxious when I know I haven't carried out an } \\
\text { assignment well }\end{array}$ & 2 & 1 & 0 \\
\hline 12 & I feel guilty when I can't carry out an assignment well & 2 & 1 & 0 \\
\hline 22 & I am ashamed to speak in front of the whole class & 2 & 1 & 0 \\
\hline \multicolumn{2}{|c|}{ Scale average (total score / 4) } \\
\hline
\end{tabular}

Table 5. Subscale Sense of self-efficacy

\begin{tabular}{|c|l|c|c|c|}
\hline $\mathbf{N}$. & \multicolumn{1}{|c|}{ Item } & Not true & Fairly true & Very true \\
\hline 2 & I am able to think quickly & 0 & 1 & 2 \\
\hline 5 & I believe I am a clever child & 0 & 1 & 2 \\
\hline 7 & When dealing with obstacles, I don't back off & 0 & 1 & 2 \\
\hline 14 & I have so much imagination & 0 & 1 & 2 \\
\hline 16 & I usually have good ideas & 0 & 1 & 2 \\
\hline 26 & I learn new things with ease & 0 & 1 & 2 \\
\hline \multicolumn{2}{|c|}{ Scale total score } & \multicolumn{2}{|c|}{} \\
\hline
\end{tabular}

Table 6. Derivation of the Total Score of the Child' School Well-being

\begin{tabular}{|l|c|}
\hline Subscale & Average Score \\
\hline 1. Satisfaction and recognition & + \\
\hline 2. Relationship with teachers & + \\
\hline 3. Relationship with classmates & + \\
\hline 4. Emotional attitude at school & + \\
\hline 5. Sense of self-efficacy & + \\
\hline Total School Well-being score & $=$ \\
\hline
\end{tabular}




\section{Outcomes and Observations}

Below the tables at time 0 and time 1 with the related assessment for each student, based on the QBS-B questionnaire; the children were randomly numbered from 1 to 20 and the data were approximated to the second decimal point.

Table 7. Assessment at Time 0

\begin{tabular}{|c|c|c|c|c|c|c|c|c|c|c|}
\hline Subscale & \multicolumn{10}{|c|}{ Average Score per Child } \\
\hline & 1 & 2 & 3 & 4 & 5 & 6 & 7 & 8 & 9 & 10 \\
\hline 1. & 1.00 & 0.50 & 0.50 & 1.25 & 1.25 & 1.25 & 1.00 & 1.25 & 1.50 & 1.00 \\
\hline 2. & 0.60 & 0.40 & 0.40 & 1.60 & 1.60 & 1.60 & 0.60 & 1.60 & 0.60 & 0.60 \\
\hline 3. & 0.40 & 0.80 & 0.80 & 1.00 & 1.00 & 1.00 & 0.40 & 1.00 & 0.80 & 0.40 \\
\hline 4. & 1.00 & 0.50 & 0.50 & 1.00 & 1.00 & 1.00 & 1.00 & 1.00 & 0.75 & 1.00 \\
\hline 5. & 0.50 & 1,17 & 1,17 & 1,17 & 0.50 & 1,17 & 0.50 & 0.50 & 1.50 & 0.50 \\
\hline $\begin{array}{l}\text { Total School Well-being } \\
\text { score Per Child }\end{array}$ & 3.50 & 3.37 & 3.37 & 6.02 & 5.35 & 6.02 & 3.50 & 5.35 & 5.15 & 3.50 \\
\hline & 11 & 12 & 13 & 14 & 15 & 16 & 17 & 18 & 19 & 20 \\
\hline 1. & 1.25 & 0.50 & 1.50 & 0.50 & 1.25 & 1.50 & 1.25 & 1.00 & 1.25 & 1.50 \\
\hline 2. & 1.60 & 0.80 & 0.80 & 0.40 & 1.40 & 0.60 & 1.60 & 0.60 & 1.60 & 0.60 \\
\hline 3. & 1.40 & 0.40 & 0.60 & 0.80 & 1.60 & 0.80 & 1.40 & 0.40 & 1.40 & 0.80 \\
\hline 4. & 0.75 & 0.50 & 0.75 & 0.50 & 0.75 & 0.75 & 0.75 & 1.00 & 0.75 & 0.75 \\
\hline 5. & 1.33 & 1,17 & 1.50 & 1,17 & 1.33 & 1.50 & 1.33 & 0.50 & 1.33 & 1.50 \\
\hline $\begin{array}{c}\text { Total School Well-being } \\
\text { score Per Child }\end{array}$ & 6.33 & 3.37 & 5.15 & 3.37 & 6.33 & 5.15 & 6.33 & 3.50 & 6.33 & 5.15 \\
\hline
\end{tabular}

Table 8. Assessment at Time 1

\begin{tabular}{|c|c|c|c|c|c|c|c|c|c|c|}
\hline Subscale & \multicolumn{10}{|c|}{ Average Score per Child } \\
\hline & $\mathbf{1}$ & $\mathbf{2}$ & $\mathbf{3}$ & $\mathbf{4}$ & $\mathbf{5}$ & $\mathbf{6}$ & $\mathbf{7}$ & $\mathbf{8}$ & $\mathbf{9}$ & $\mathbf{1 0}$ \\
\hline 1. & 1.25 & 1.25 & 1.25 & 1.50 & 1.50 & 1.50 & 1.25 & 1.50 & 1.75 & 1.25 \\
\hline 2. & 1.20 & 1.00 & 1.20 & 1.80 & 1.80 & 1.80 & 1.20 & 1.80 & 0.60 & 1.20 \\
\hline 3. & 1.00 & 1.20 & 1.00 & 1.40 & 1.40 & 1.40 & 1.00 & 1.40 & 1.60 & 1.00 \\
\hline 4. & 1.25 & 1.25 & 1.25 & 1.75 & 1.75 & 1.75 & 1.25 & 1.75 & 1.75 & 1.25 \\
\hline 5. & 1.50 & 1.50 & 1.50 & 1.50 & 1.50 & 1,17 & 1.50 & 1,17 & 1.67 & 1,17 \\
\hline $\begin{array}{c}\text { Total School Well-being } \\
\text { score Per Child }\end{array}$ & 6.20 & 5.20 & 5.20 & 7.95 & 7.95 & 7.62 & 6.20 & 7.62 & 7.37 & 5,87 \\
\hline & $\mathbf{1 1}$ & $\mathbf{1 2}$ & $\mathbf{1 3}$ & $\mathbf{1 4}$ & $\mathbf{1 5}$ & $\mathbf{1 6}$ & $\mathbf{1 7}$ & $\mathbf{1 8}$ & $\mathbf{1 9}$ & $\mathbf{2 0}$ \\
\hline 1. & 1.75 & 1.25 & 1.75 & 1.25 & 1.75 & 1.75 & 1.75 & 1.25 & 1.75 & 1.75 \\
\hline 2. & 1.80 & 1.20 & 0.60 & 1.00 & 1.80 & 0.60 & 1.80 & 1.20 & 1.80 & 0.60 \\
\hline 3. & 1.60 & 1.00 & 1.60 & 1.20 & 1.60 & 1.60 & 1.60 & 1.00 & 1.60 & 1.60 \\
\hline 4. & 1.75 & 1.25 & 1.75 & 1.25 & 1.75 & 1.75 & 1.75 & 1.25 & 1.75 & 1.75 \\
\hline 5. & 1.67 & 1.67 & 1.67 & 1.50 & 1.67 & 1.67 & 1.67 & 1,17 & 1.67 & 1.67 \\
\hline $\begin{array}{l}\text { Total School Well-being } \\
\text { score Per Child }\end{array}$ & 8.57 & 5.37 & 7.37 & 5.20 & 8.57 & 7.37 & 8.57 & 5,87 & 8.57 & 7.37 \\
\hline
\end{tabular}


First of all, it should be noted that no student exceeded the absence limit, so the experimental phase dropout is 0 .

There was a general improvement in the well-being state in the various subscales and for almost all of the students, proving how much sports activity is able to influence the individual's key factors, even in primary school age, which affect the school dimension. In particular, the outcomes obtained in the sociorelational factors are significant both with regard to one's own "peers" and in relation to teachers; this circumstance is attributable to the ability of team sport to positively stimulate, on the one hand, the "team working" and the will to pursue a common goal through individual commitment, and on the other hand, the respect of the authoritarian figure of the coach as a guide towards personal and group satisfaction (Ascione, Di Palma, Napolitano, 2018; Belfiore et al, 2019; Di Palma, Ascione, Peluso Cassese, 2018; Di Palma, Raiola, Tafuri, 2016; Peluso Cassese et al, 2018). Moreover, it needs to take into consideration the progress in subscales n. 1, 4 and 5 where sports activity was able to act positively in the construction of self-esteem and self-efficacy in children (Ascione, Di Palma, Rosa, 2019; Di Palma, Ascione, Napolitano, 2018; Di Palma et al, 2018; Raiola, Tafuri, 2015).

\section{CONCLUSIONS}

School well-being, in a period of particular attention to socio-pedagogical aspects within the school system, is becoming increasingly important. The educational flow itself is strongly influenced, because, like any other social context, the group acting in an environment with a high level of well-being has higher possibilities of effectively and quickly reaching its goals; therefore, educational learning is promoted in the school system.

In this scenario, we wanted to bring to light the concrete potential of a sports laboratory to improve the well-being state in the context of primary school. The results proved significant in all the key determinants of school well-being for all the children of the sample analysed, without a relevant distinction based on gender. This makes it possible to put forward the proposal to consider the presence of sports activities as a constant educational reality in the school system, capable of affecting the social and pedagogical aspects at any level. Obviously, one limit of this work is certainly the high number and the scarce heterogeneity of the evaluated sample. Future research hints, in this regard, could be precisely the increase in the number of the sample and its differentiation, both in terms of education and type and address of the school context; we could also analyse the feedback in terms of didactic learning following the improvement of the school well-being, in order to characterize the experimental pedagogical proposal introduced also in a didactic key.

\section{AUTHORS“ CONTRIBUTIONS}

The manuscript is the result of a collective work by the authors, the specific contribution of which is to be referred to as follows: paragraphs n. 1, n. 2 and Conclusions are to be attributed to Antonio Ascione, paragraph n. 3 to Davide Di Palma and Introduction to Salvatore lovino.

\section{REFERENCES}

Allison, P. J., Locker, D., \& Feine, J. S. (1997). Quality of life: a dynamic construct. Social science \& medicine, 45(2), 221-230. https://doi.org/10.1016/s0277-9536(96)00339-5 
Antonio Ascione, Davide Di Palma, Roberta Rosa (2019). Innovative educational methodologies and corporeity factor. Journal of Human Sport \& Exercise. https://doi.org/10.14198/ihse.2019.14.proc2.02

Ascione A, Di Palma D., Napolitano S. (2018). social inclusion and education through sport and technology. Sport Science 11 (2018) 1: 52-56. e-ISSN: 1840-3670 p-ISSN: 1840-3662.

Bandura, A., Zimmerman, B. J., Cleary, T. J., Schunk, D. H., Meece, J. L., Caprara, G. V., ... \& Regalia, C. (2007). L'autoefficacia degli adolescenti: dalla scuola ai comportamenti a rischio. F. Pajares, \& T. Urdan (Eds.). Erickson Study Center.

Belfiore P., Tafuri D., Ascione A., Di Palma D. (2019). sport education and health promotion in the school. Acta Medica Mediterranea, p. 1089-1091. https://doi.org/10.19193/0393-6384_2019_2_167

Caprara, G. V. (Ed.). (2001). La valutazione dell'autoefficacia. Costrutti e strumenti. Edizioni Erickson.

Crocetti, E. (2014). II contesto scolastico in adolescenza: identità, benessere e dinamiche relazionali. Studi Zancan, 3, 80-86.

Di Palma D, Ascione A, Belfiore P. (2018) Experimental Approach Of Water Polo Training To Improve Psycho-Physical. Acta Medica Mediterranea 2018; 34: 1253. https://doi.org/10.19193/0393638420185192

Di Palma D., Ascione A., Masala D. (2018). Pallanuoto: dalle Metodologie dell'Allenamento ai Benefici Psico-Fisici e Sociali. Formazione \& Insegnamento, vol. XVI, p. 205-212, ISSN: 1973-4778.

Di Palma D., Ascione A., Napolitano S. (2018). Education to school inclusion through sport. Sport Science, vol. 11, p. 42-46, ISSN: 1840-3670.

Di Palma D., Tafuri, D., Ascione A., Raiola, A. (2018). Social, Tourism and Educational development through Sport. Journal of Physical Education and Sport $®$ (JPES), 18 Supplement issue 1, Art 67, pp. $473-478$.

Di Palma, D., Ascione, A., Peluso Cassese, F. (2017). Gestire lo sport per uno sviluppo educativo. Giornale Italiano della Ricerca Educativa, vol. 18, p. 59-66.

Di Palma, D., Raiola, G., \& Tafuri, D. (2016). Disability and Sport Management: a systematic review of the literature. Journal of Physical Education and Sport, 16(3), 785.

Diener, E., \& Larsen, R. J. (1993). The experience of emotional well-being. In M. Lewis \& JM Haviland (Eds.), Handbook of emotions (pp. 405-415). New York, NY, US: Guilford Press.

Gatta, G. (2009). Conoscere la pallanuoto. Scienza \& Sport, 2, 54-57.

Guetano, R., Lipoma, M., \& Tafuri, D. (2015). Postural control in young soccer players: differences between the cognitive approach and ecological-dynamic one. Journal of Human Sport and Exercise, 10(1). https://doi.org/10.14198/ihse.2015.10.proc1.29

Mariani, U. (2001). Educazione alla salute nella scuola. Costruzione del benessere e prevenzione del disagio (Vol. 36). Erickson Editions.

Marzocchi, G. M., \& Tobia, V. (2015). QBS 8-13: Questionari per la valutazione del benessere scolastico e identificazione dei fattori di rischio. Erickson Study Center Editions.

Maslow, A. H. (1970). Motivation and personality (2nd ed.). New York: Harper \& Row.

Napolitano, S., Tursi, D., Di Tore, P. A., \& Raiola, G. (2013). Tactis-based water polo training. Journal of Human Sport \& Exercise. https://doi.org/10.4100/hhse.2012.8.proc2.29

Peluso Cassese F., Di Palma D., Ascione A., Tafuri D. (2018). Educare con lo sport: una risorsa multivaloriale. Formazione \& Insegnamento, vol. XVI, p. 173-180.

Petrillo, G. (2008). Promozione della salute e del benessere degli adolescenti nel contesto scolastico. Psicologia della salute. https://doi.org/10.3280/pds2019-002003

Raiola, G., \& Tafuri, D. (2015). Teaching method of physical education and sports by prescriptive or heuristic learning. Journal of Human Sport and Exercise, 10(1). https://doi.org/10.14198/ihse.2015.10.proc1.28 
Ryan, R. M., \& Deci, E. L. (2001). On happiness and human potentials: A review of research on hedonic and eudaimonic well-being. Annual review of psychology, 52(1), 141-166. https://doi.org/10.1146/annurev.psych.52.1.141

Steca, P., Ryff, C. D., D'Alessandro, S., \& Delle Fratte, A. (2002). II benessere psicologico: differenze di genere e di età nel contesto italiano. Psicologia della Salute.

Varni, J. W., Seid, M., \& Rode, C. A. (1999). The PedsQL ${ }^{\mathrm{TM}}$ : measurement model for the pediatric quality of life inventory. Medical care, 126-139. https://doi.org/10.1097/00005650-199902000-00003 